\title{
Comparison of pharmacological properties and phytochemical constituents of in vitro propagated and naturally occurring liverwort Lunularia cruciata
}

\author{
Sumira Mukhia', Palash Mandal ${ }^{*}$, D. K. Singh ${ }^{2}$ and Devendra Singh ${ }^{2}$
}

\begin{abstract}
Background: Study of phytochemicals and pharmacological properties of bryophytes has been neglected for a long time because of the three main reasons i.e. (i) difficulty in collection in large amount for analysis; (ii) their availablility only in particular season and (iii) their restricted geographic distribution. So, the aim of this work was to propagate Lunularia cruciata under in vitro condition for comparing its pharmacological properties and phytocmecial constituents with naturally grown counterparts.

Method: Axenic culture of L. cruciata was established by propagating gemmae under in vitro condition. Appropriate culture conditions, media, and the effect of hormones on growth and development were studied. The phytochemical composition was determined by GC-MS analysis and pharmacological activity was evaluated by assessing the antioxidant and anti-diabetic activities. For the antioxidant activity ABTS ${ }^{+}$[2,2'-azino-bis(3-ethylbenzothiazoline-6-sulphonic acid)], $\mathrm{DPPH}^{*}$ (2,2-diphenyl-1-picrylhydrazyl) and metal chelating assays were done and for evaluation of the in vitro anti-diabetic activity a-glucosidase and a-amylase inhibitory activities were done.

Result: Growth of L. cruciata was recorded in half strength MS media. Benzylaminopurine (BAP: 2 mg/L) and 1Naphtheleneacetic acid (NAA: $0.5 \mathrm{mg} / \mathrm{L}$ ) were the successful hormonal combination. GC-MS analysis revealed the existence of nine key compounds in both in vitro and naturally grown L. cruciata. Result of antioxidant and anti-diabetic activity showed that in vitro grown $L$. cruciata has a more or less similar antioxidant and anti-diabetic activities as naturally grown ones. This result confirms the possibility of using in vitro grown plants in place of naturally grown plants for research and clinical purposes.
\end{abstract}

Keywords: In vitro, Culture, Liverworts, Phytochemicals, Antioxidant, Anti-diabetic

\section{Background}

Bryophytes are the second largest taxonomic group of the plant kingdom and are an integral part of biodiversity. Despite having many important ecological roles, studies on biochemical attributes of this group of plants have been neglected for a long time. In recent times numerous distinct bioactive substances have been isolated from liverworts and mosses [1-3]. Even compounds that are entirely new to plant kingdom have been obtained

\footnotetext{
* Correspondence: nbubotanypm@gmail.com

${ }^{1}$ Plant Physiology and Pharmacognosy Research Laboratory, Department of Botany, North Bengal University, P.O: NBU, Raja Rammohunpur, District, Darjeeling, West Bengal, India

Full list of author information is available at the end of the article
}

from this comparatively unexplored group of plants, mainly from liverworts [4]. Well expressed antibacterial, antifungal, antioxidant activity and cytotoxicity with respect to cancer cell have been demonstrated in the number of bryophytes [5-9]. Apart from this, anti-diabetic, antiplatelet, insecticidal and many other activities have been confirmed by several studies [10-12]. Traditionally some bryophyte species were applied as ethnomedicine by many tribes worldwide. In spite of being a treasure house for a large number of phytochemicals showing high biological activity, the investigations in this group are still in a nascent stage. Biochemical studies on these plants are restricted mainly due to their i) inadequate

(c) The Author(s). 2019 Open Access This article is distributed under the terms of the Creative Commons Attribution 4.0 International License (http://creativecommons.org/licenses/by/4.0/), which permits unrestricted use, distribution, and reproduction in any medium, provided you give appropriate credit to the original author(s) and the source, provide a link to the Creative Commons license, and indicate if changes were made. The Creative Commons Public Domain Dedication waiver (http://creativecommons.org/publicdomain/zero/1.0/) applies to the data made available in this article, unless otherwise stated. 
availability in nature ii) seasonal dependency and iii) habitat specificity. These impediments, however, can be successfully addressed by in vitro propagation. Although culturing plant tissues and organs under axenic conditions was first established and profitably employed in bryophytes, especially mosses [13], bryophytes did not retain for long their rightful place as a highly favored research object. Besides the problems of the establishment of axenic culture, it is often problems of material availability, the genetic variability of material, disposal of axenic organisms living on bryophytes and low level of species biology knowledge [14]. Even though researchers became successful in establishing axenic cultivation, their works are mainly focused on rare species conservation and their ex-situ reintroduction [15-18]. The works inclined towards addressing the problem of material availability for research purposes are rather rare. This study aims to compare the phytochemical composition and pharmacological properties of axenically and naturally grown liverwort L. cruciata to find out whether the axenically cultured bryophytes can be used as a substitute to naturally grown ones to meet up the demands of sample available for use in research purposes.

\section{Methods}

\section{Plant material collection and axenic culture}

Plant sample Lunularia cruciata was collected from Darjeeling, Eastern Himalaya, India and was identified by Dr. D.K. Singh and Dr. Devendra Singh, Botanical Survey of India. The voucher specimen was deposited in the Central National Herbarium, Kolkata [51,891/17 (CAL)]. Sporophytes of liverworts are difficult to collect in proper stage, so in this study axenic culture was initiated from gemmae. Gemmae were at first carefully taken out from gemmae cup and rinsed with distilled water. After rinsing, gammae were sterilized with 1, 2, 3 and $4 \%$ sodium hypochlorite solution for $30 \mathrm{~s}, 1,2$ and 4 min. After sterilization, gemmae were immediately rinsed with sterilized double distilled water to determine optimum concentration and exposure time of sodium hypochlorite solution. A different basal medium like such as Murashige and Skoog medium, Gamborg G5 medium and Knop's medium were used in this study. The $\mathrm{pH}$ of the media was maintained at 5.8 before autoclaving and gelled using $0.8 \%$ agar. Glasswares and media were sterilized by autoclaving at $15 \mathrm{lb}$./sq. in for $15 \mathrm{~min}$. Gemmae were inoculated in the media inside the laminar air flow cabinet and maintained under controlled, aseptic condition. Cultures were retained at $21 \pm$ $2{ }^{\circ} \mathrm{C}$ under the illumination of $4000-5000 \mathrm{~lx}$; alternate light and dark period of 14 and $10 \mathrm{~h}$ respectively. After germination, gemmae were transferred onto media with different concentrations of growth regulators:1-
Naphthalene acetic acid $(0.25-5 \mathrm{mg} / \mathrm{L})$ and Benzylaminopurine $(1-4 \mathrm{mg} / \mathrm{L})$.

\section{Plant extracts preparation}

L. cruciata collected from the natural and axenic condition were firstly dried and ground into a fine powder. Powdered samples were refluxed using methanol for $4 \mathrm{~h}$. The extract obtained was then filtered, concentrated and used for experimental purposes.

\section{Gas chromatography-mass spectrometry analysis}

Perkin-Elmer GC Clarus 500 system with AOC-20i autosampler and a Gas chromatograph interfaced to a Mass Spectrometer were used. The separations were done using Elite-5MS (5\% diphenyl / 95\% dimethyl polysiloxane) capillary tube $(30 \times 0.25 \mu \mathrm{m}$ ID $\times 0.25 \mu \mathrm{m}$ film thickness). Helium (99.9\%) was used as the carrier gas at a constant flow rate of $1 \mathrm{ml}$ for $1 \mathrm{~min}$, with a split flow rate of $10.0 \mathrm{~mL} / \mathrm{min}$. The mass spectrometer was operated at $70 \mathrm{ev}$ ionization energy, with a scanning interval of $0.5 \mathrm{~s}$, scanned from 45 to $450 \mathrm{~m} / \mathrm{z}$ (mass/charge). The column temperature was maintained at $250{ }^{\circ} \mathrm{C}$ and the ion source temperature was $200^{\circ} \mathrm{C}$.

The column temperature was programmed at $110^{\circ} \mathrm{C}$ for $2 \mathrm{~min}$, with an increase of $10^{\circ} \mathrm{C} / \mathrm{min}$ to $200^{\circ} \mathrm{C}$, then $5^{\circ} \mathrm{C} / \mathrm{min}$ to $280^{\circ} \mathrm{C}$ and finally held at $280^{\circ} \mathrm{C}$ for $9 \mathrm{~min}$, with the total runtime of $36 \mathrm{~min}$. A sample volume of $2 \mu \mathrm{l}$ was loaded in a mode injector. The mass detector used was TurboMass GoldTM PerkinElmer; the software used for mass spectral analysis and chromatogram was Turbo-Mass ver-5.2. MS fragmentation patterns and retention time of the compounds were compared with the NIST database. The relative percentage of compounds was quantified by comparing the average peak area to the total area.

\section{DPPH (2,2-diphenyl-1-picrylhydrazyl) radical scavenging activity}

$\mathrm{DPPH}^{*}$ scavenging activity was studied by following the method of Sidduraju et al. [19]. DPPH' solution was prepared by dissolving $4 \mathrm{mg} \mathrm{DPPH}^{*}$ in $100 \mathrm{ml}$ methanol. The reaction was initiated by mixing $2 \mathrm{ml}$ of DPPH solution with $200 \mu \mathrm{l}$ of plant extract. The reduction in the solution colour was estimated spectrophotometrically at 517 $\mathrm{nm}$. DPPH scavenging activity of the sample was calculated by using the following formula:

$$
\begin{aligned}
\% \mathrm{I} & =\left[\left(\mathrm{A}_{0}-\mathrm{A}_{1}\right) / \mathrm{A}_{0}\right] \times 100, \text { where }\left(\mathrm{I}=\text { inhibition, } \mathrm{A}_{0}\right. \\
& \left.=\text { absorbance of blank, } \mathrm{A}_{1}=\text { absorbance of test sample }\right) .
\end{aligned}
$$

\section{$\mathrm{ABTS}^{+}$scavenging activity}

$\mathrm{ABTS}^{+}$scavenging activity of plants was estimated according to the method of $\mathrm{Li}$ et al. [20] with few 
modifications. For the preparation of $7 \mathrm{mM} \mathrm{ABTS}^{+}$solution, $38 \mathrm{mg} \mathrm{ABTS}{ }^{+}$was dissolved in $10 \mathrm{ml}$ methanol. In a different conical flask, $6.4 \mathrm{mg}$ Potassium persulphate was dissolved in $10 \mathrm{ml}$ water. These two solutions were mixed together in equal proportion. The solution was then diluted eight times with water and used for the assay. In the assay $2 \mathrm{ml}$ of $7 \mathrm{mM} \mathrm{ABTS}{ }^{+}$solution was added to $1 \mathrm{ml}$ sample. The mixture was then incubated for $10 \mathrm{~min}$. Absorbance was measured at $734 \mathrm{~nm}$. The $\mathrm{ABTS}^{+}$scavenging activity was calculated by using the following formula:

$$
\begin{aligned}
\% \mathrm{I} & =\left[\left(\mathrm{A}_{0}-\mathrm{A}_{1}\right) / \mathrm{A}_{0}\right] \times 100, \text { where }\left(\mathrm{I}=\text { inhibition, } \mathrm{A}_{0}\right. \\
& \left.=\text { absorbance of blank, } \mathrm{A}_{1}=\text { absorbance of test sample }\right) .
\end{aligned}
$$

\section{Metal chelating activity}

Metal chelating activity was estimated following the method of Dinis et al. [21]. At first $400 \mu \mathrm{l}$ of the sample was mixed with $1.6 \mathrm{ml}$ methanol. This step is followed by the addition of $40 \mu \mathrm{l}$ of $2 \mathrm{mM} \mathrm{FeCl} 2$ and $80 \mu \mathrm{l}$ of 5 $\mathrm{mM}$ Ferrozine. The mixture was then incubated for 10 min before measuring absorbance at $562 \mathrm{~nm}$. Metal chelating activity was calculated by using the following formula:

$$
\begin{aligned}
\% \mathrm{I} & =\left[\left(\mathrm{A}_{0}-\mathrm{A}_{1}\right) / \mathrm{A}_{0}\right] \times 100, \text { where }\left(\mathrm{I}=\text { inhibition, } \mathrm{A}_{0}\right. \\
& \left.=\text { absorbance of blank, } \mathrm{A}_{1}=\text { absorbance of test sample }\right) .
\end{aligned}
$$

\section{a-Glucosidase inhibitory activity}

The method described by Kim et al. [22] was followed with a slight modification to determine the $\alpha$-glucosidase inhibitory activity of the studied plant. The reaction was initiated by mixing $2.5 \mathrm{ml} 0.1 \mathrm{M}$ phosphate buffer [pH 6.8], $0.5 \mathrm{ml}$ reduced glutathione ( $9.2 \mathrm{mg}$ glutathione dissolved in $10 \mathrm{ml}$ buffer) and 0.1 $\mathrm{ml}$ enzyme $(10 \mu \mathrm{g} / \mathrm{ml})$. After $15 \mathrm{~min}$ of incubation, $0.5 \mathrm{ml}$ of sample and $0.25 \mathrm{ml}$ of $\rho$-NPG $(30 \mathrm{mg} \rho$ NPG dissolved in $10 \mathrm{ml}$ buffer) were added to the mixture. It was again incubated for $15 \mathrm{~min}$ and the reaction was finally stopped by adding $4 \mathrm{ml}$ of $0.1 \mathrm{M}$ $\mathrm{Na}_{2} \mathrm{CO}_{3}$. Absorbance was measured at $405 \mathrm{~nm}$. $\alpha-$ glucosidase inhibitory activity was calculated by using the following formula:

$$
\begin{aligned}
\% \mathrm{I} & =\left[1-\left(\mathrm{A}_{\mathrm{s}}-\mathrm{A}_{\mathrm{b}}\right) / \mathrm{A}_{\mathrm{c}}\right] \times 100 \text { where, } \mathrm{A}_{\mathrm{s}} \\
& =\text { absorbance of sample, } \mathrm{A}_{\mathrm{b}} \\
& =\text { absorbance of blank, } \mathrm{A}_{\mathrm{c}} \\
& =\text { absorbance of control }
\end{aligned}
$$

\section{a-Amylase inhibitory activity}

The $\alpha$-amylase inhibitory activity was estimated following the method of Kim et al. [22]. A mixture of $0.1 \mathrm{ml}$ of sample, $0.1 \mathrm{ml}$ of an enzyme, and $0.3 \mathrm{ml}$ of Sodium- potassium buffer ( $\mathrm{pH}$ 6.9) was incubated for $30 \mathrm{~min}$. After $30 \mathrm{~min} 0.5 \mathrm{ml}$ of starch $(100 \mathrm{mg}$ starch in $10 \mathrm{ml}$ buffer) was added to the mixture. The reaction was stopped by adding $1 \mathrm{ml}$ of dinitrosalicylic acid after 5 min. Absorbance was measured at $540 \mathrm{~nm}$. $\alpha$-amylase inhibitory activity was calculated by using the following formula:

$$
\begin{aligned}
\% \mathrm{I} & =\left[\mathrm{A}_{540} \mathrm{C}-\mathrm{A}_{540} \mathrm{E}\right] /\left[\mathrm{A}_{540} \mathrm{C}\right] \times 100 \text { where, } \mathrm{A}_{540} \mathrm{C} \\
& =\text { absorbance of control, } \mathrm{A}_{540} \mathrm{E} \\
& =\text { absorbance of extract }
\end{aligned}
$$

\section{Statistical analysis}

The data were collected in triplicate. $\mathrm{IC}_{50}$ values and standard error of estimates were determined by using MS Excel 2007 (Microsoft, Redmond, WA, USA). Turkey's Range Test through DSAASTAT software (version 1.002; DSAASTAT, Peruglia, Italy) was used for comparing means; $p<0.05$ was considered to be statistically significant for differences in the mean level of components.

\section{Results}

\section{Axenic culture of $L$. cruciata}

Axenic culture of L. cruciata was initiated from gemmae as it is difficult to collect spores in the proper stage. Gemmae started germinating after 8-12 days of inoculation. Gemmae increased in size absorbing moisture and turned green in colour. Half strength Murashige and Skoog (MS) medium in alternate light (L) and dark condition (D) of $14 \mathrm{~h} \mathrm{~L} /$ $10 \mathrm{~h} \mathrm{D}$ was found to be most suitable, supporting the maximum number of gemmae germination. Germination of gemmae was also noticed in Knop's micronutrient medium, but these gemmae failed to grow. Gemmae failed to germinate completely in half and full strength Gamborg B-5 medium. Continuous illumination of $4000-5000 \mathrm{~lx}$ and temperature $21^{\circ} \pm$ $2{ }^{\circ} \mathrm{C}$ was used. Sterilization with $1 \%$ sodium hypochlorite for $4 \mathrm{~min}$ or $4 \%$ sodium hypochlorite for 1 min was proved effective as gemmae remained alive and most of the microbes were killed. Exposure to a higher concentration of sterilant even for a few seconds was harmful. Similarly, treatment of the gemmae in lower concentration for a long time was also found to be lethal.

The early sign of germination was the change in the colour of gemmae from brown to green. The highest percentage $(90 \%)$ of germination was observed in half strength MS media followed by half strength Knop's medium (20\%), while no germination was noticed in full strength MS media, Knop's medium, Gamborg B5 medium, and half strength Gamborg G5 
Table 1 Effect of BAP/NAA on gemmae germination

\begin{tabular}{llll}
\hline & NAA $(0.5 \mathrm{mg} / \mathrm{L})$ & NAA $(1 \mathrm{mg} / \mathrm{L})$ & NAA $(2 \mathrm{mg} / \mathrm{L})$ \\
\hline BAP $(1 \mathrm{mg})$ & No germination & No germination & No germination \\
BAP (2 mg) & Germination & No germination & No germination \\
BAP (3 mg) & No germination & No germination & No germination \\
\hline
\end{tabular}

medium. Gemmae then started to increase in size and green colour became more prominent. Young thalli started developing from gemmae after 8-12 days. After 2 weeks, thalli turned into dark blackish green coloured undifferentiated tissue called callus. At this stage, the profound effect of growth regulators like BAP and NAA was noticed. Hormone combination: 2 $\mathrm{mg} / \mathrm{L}$ BAP and $0.5 \mathrm{mg} / \mathrm{L}$ NAA successfully initiated the differentiation of callus (Table 1). A higher concentration of growth regulators had shown a detrimental effect on the callus. A large number of rhizoids growing from all parts of callus were noticed in the media containing $0.5 \mathrm{mg} / \mathrm{L}$ NAA hindering further differentiation of tissues. The transfer of callus in the media containing $4 \mathrm{mg} / \mathrm{L} \mathrm{BAP}$ and $0.2 \mathrm{mg} / \mathrm{L} \mathrm{NAA}$ lead to the development of thallus from undifferentiated tissue with a much-reduced number of rhizoids on the dorsal side of the thallus. Under the illumination of $4000-5000 \mathrm{~lx}$ with alternate light and dark condition of $14 \mathrm{~h}$ and $10 \mathrm{~h}$ the thallus further continued to branch and grow (Fig. 1). Mature thallus was used to compare the pharmacological properties and phytochemical composition of in vitro grown and naturally grown $L$. cruciata.

\section{Comparison of pharmacological activities Antioxidant activity}

$\mathrm{DPPH}^{*}$ is commonly used for investing the free radical scavenging properties of natural compounds. Naturally grown $L$. cruciata scavenged 73,40 and $24 \% \mathrm{DPPH}$ radicals, while, in vitro grown $L$. cruciata scavenged 48,35 and $22 \%$ DPPH radicals at concentrations 650 , 350 and $250 \mu \mathrm{g} / \mathrm{ml}$ (Fig. 2). ABTS $^{+}$scavenging assay is also widely used in the in vitro studies to assess the antioxidant property of natural compounds. In vitro grown $L$. cruciata showed higher $\mathrm{ABTS}^{+}$scavenging activity than naturally grown ones. The result showed that $2 \mathrm{mg} / \mathrm{ml}$ of naturally grown $L$. cruciata extract scavenged $88 \% \mathrm{ABTS}^{+}$and the same concentration of in vitro grown L. cruciata scavenged 98\% ABTS $^{+}$(Fig. 3).

The metal chelating assay is another important antioxidant assay. Metal ions accelerate lipid peroxidation by decomposing hydrogen peroxide to alkoxyl and peroxyl radicals. Transition metal also reacts with hydrogen peroxide to form hydroxyl ion. Metal

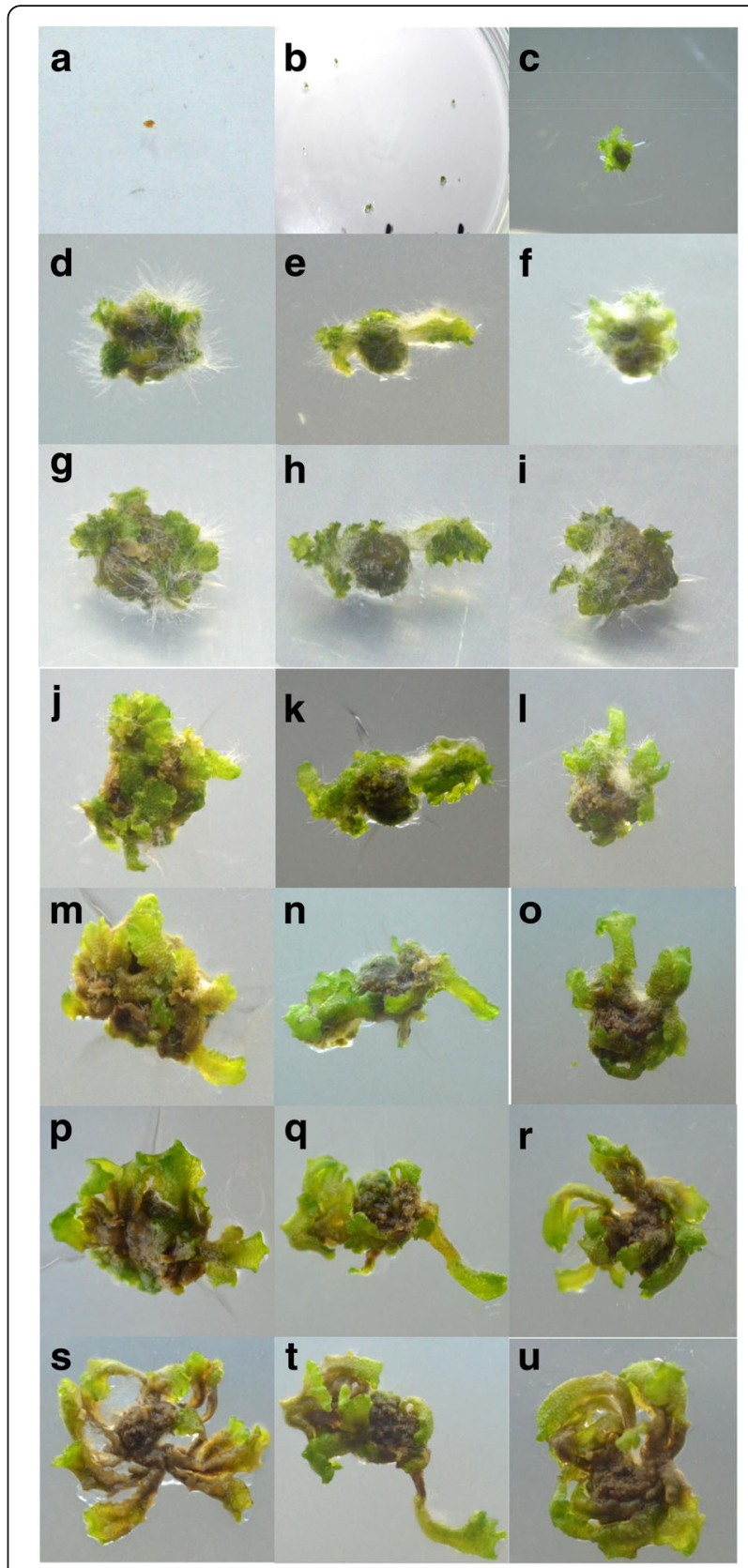

Fig. 1 In vitro growth of L. cruciata. a. gemmae placed on MS media b-c. Germinating gemmae after 16-17 days d-f. Thallus and rhizoids developed from gemmae $\mathbf{g}$-i. Well developed thalli after repeated sub culturing $\mathbf{j}-\mathbf{l}$. Control of excessive growth of rhizoids by alternating hormone ratio and growth of dichotomously branched thalli. $\mathbf{m}-\mathbf{u}$ Growth and maturation of thalli (continuation)

chelating activity has high perceptibility in the living system as it lowers the concentration of transition metals in the process like lipid peroxidation. Metal chelating activity of in vitro and naturally grown $L$. cruciata differed largely. A reduction of $85 \%$ of 


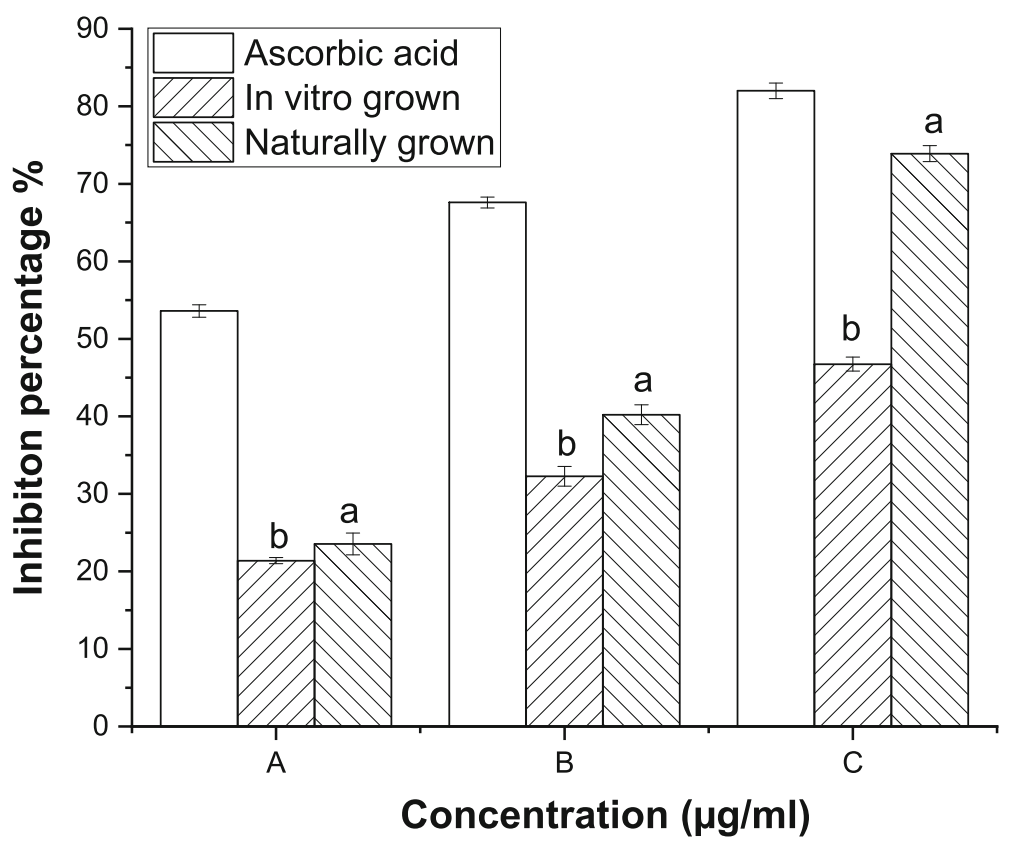

Fig. $2 \mathrm{DPPH}^{*}$ scavenging activity of in vitro and naturally grown L. cruciata and their comparison with standard Ascorbic acid. Values with different letters $(a, b)$ are significantly $(p<0.05)$ different from each other by Turkey's multiple range test

Explanation of figure caption:

$\begin{array}{lc} & \text { Conc. of in vitro grown plants } \\ \mathbf{A}= & 250 \mu \mathrm{g} / \mathrm{ml} \\ \mathbf{B}= & 350 \mu \mathrm{g} / \mathrm{ml} \\ \mathbf{C}= & 650 \mu \mathrm{g} / \mathrm{ml}\end{array}$

\author{
Conc. of naturally grown plants \\ $250 \mu \mathrm{g} / \mathrm{ml}$ \\ $350 \mu \mathrm{g} / \mathrm{ml}$ \\ $650 \mu \mathrm{g} / \mathrm{ml}$
}

\section{Conc. of Standard \\ $250 \mu \mathrm{g} / \mathrm{ml}$ \\ $350 \mu \mathrm{g} / \mathrm{ml}$ \\ $650 \mu \mathrm{g} / \mathrm{ml}$}

ferrous ion concentration was shown by naturally grown $L$. cruciata while $46 \%$ reduction in ferrous ion concentration was shown by in vitro grown $L$. cruciata when the concentration of plant sample was 4.5 $\mathrm{mg} / \mathrm{ml}$ in both the cases (Fig. 4).

\section{Anti-diabetic activity}

Type 2 diabetes mellitus can be managed by controlling the activity of $\alpha$-glucosidase and $\alpha$-amylase enzymes. L. cruciata obtained from both axenic and natural source showed good $\alpha$-glucosidase and $\alpha$ amylase inhibitory activity. In vitro grown $L$. cruciata inhibited 38, 40 and $60 \% \alpha$-glucosidase activity and naturally grown $L$. cruciata inhibited 44, 55 and $88 \%$ $\alpha$-glucosidase activity at concentrations $0.35,0.65$ and $35 \mathrm{mg} / \mathrm{ml}$ (Fig. 5). While, in vitro grown $L$. cruciata showed 50, 32 and 28\% inhibition of $\alpha$-amylase activity and naturally grown $L$. cruciata showed inhibition of 76,70 and $68 \% \alpha$-amylase activity at concentrations $0.30,0.60$ and $3 \mathrm{mg} / \mathrm{ml}$ (Fig. 6).

\section{Phytochemical analysis}

The GC-MS analysis was performed to study the chemical profile of in vitro and naturally grown $L$. cruciata. Methanolic extract of in vitro and naturally grown plants showed the presence of alkaloids, flavonoids, terpenes, fatty acid, aliphatic hydrocarbon and acyclic alkanes on analyses (Figs. 7 and 8). Presence of 9 compounds each has been found in methanolic extract of naturally grown and in vitro propagated L. cruciata (Figs. 9 and 10). Phytochemicals present in methanolic extract of in vitro grown $L$. cruciata were 1Butylpiperidine; 3-Hydroxy-2-[(5-oxo-1-cyclopenten-1-yl) methyl]-2-cyclohexen-1-one; flavones; 3-Hydroxyflavone, Ethyl tetradecanoate; Phytol; Z-13-octadecenyl acetate; Isopropyl stearate, and 2,4-Tricosanedione (Table 2). Phytochemicals present in methanolic extract of naturally grown plants were [12]-thujopsene; flavones; Methyl 11cyclopentaneundecanoate; Cyclopentaneundecanoic acid; Methyl (13E,16E)- 13,16-octadecadienoate; Phytol; Deoxy aspidodispermine; Methyl (13E)-13-docosenoate, and Methyl 2-\{1-acetyl-5-ethyl-2-[3-(2-hydroxyethyl)-1H-indol-2yl]-4-piperidinyl\} propanoate (Table 3). 


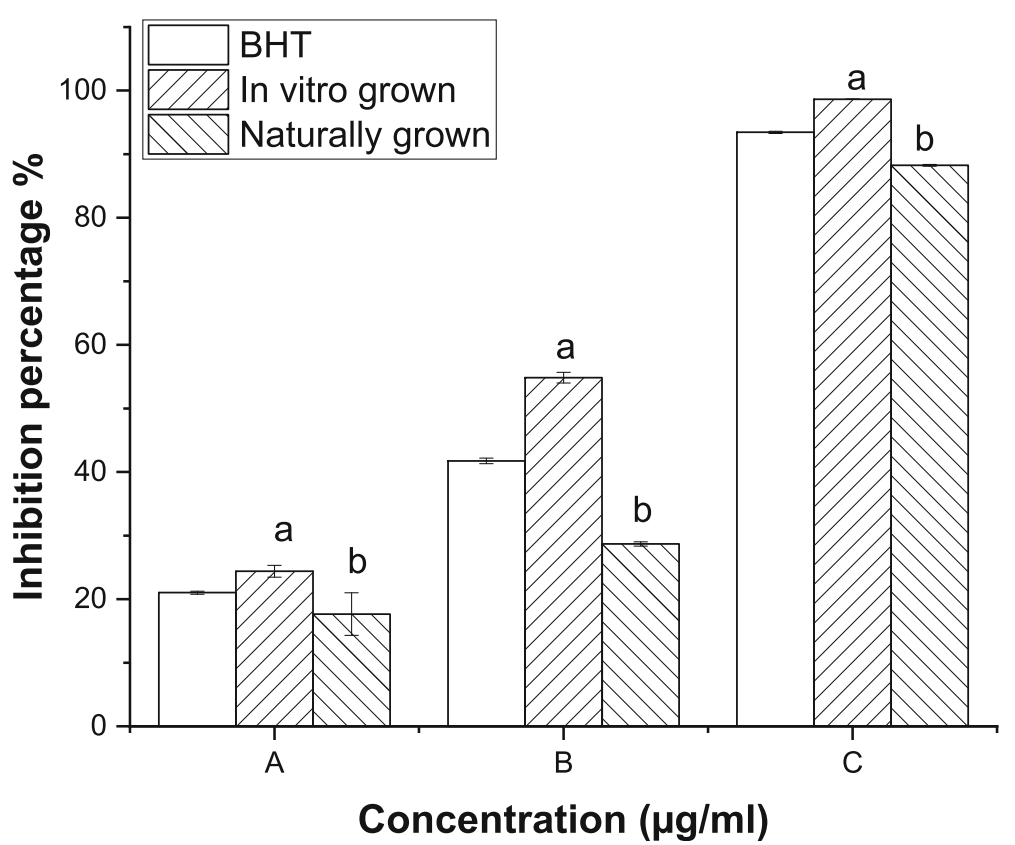

Fig. $3 \mathrm{ABTS}^{+}$scavenging activity of in vitro and naturally grown L. cruciata and their comparison with standard BHT. Values with different letters $(a, b)$ are significantly $(p<0.05)$ different from each other by Turkey's multiple range test

\section{Explanation of figure caption:}

$\begin{array}{lc} & \text { Conc. of in vitro grown plants } \\ \mathbf{A}= & 200 \mu \mathrm{g} / \mathrm{ml} \\ \mathbf{B}= & 400 \mu \mathrm{g} / \mathrm{ml} \\ \mathbf{C}= & 2000 \mu \mathrm{g} / \mathrm{ml}\end{array}$

\author{
Conc. of naturally grown plants \\ $200 \mu \mathrm{g} / \mathrm{ml}$ \\ $400 \mu \mathrm{g} / \mathrm{ml}$ \\ $2000 \mu \mathrm{g} / \mathrm{ml}$
}

\section{Conc. of Standard \\ $25 \mu \mathrm{g} / \mathrm{ml}$ \\ $50 \mu \mathrm{g} / \mathrm{ml}$ \\ $75 \mu \mathrm{g} / \mathrm{ml}$}

GC-MS results have shown that in vitro and naturally grown $L$. cruciata have similar phytochemical compositions (Table 4). Phytol and flavones were present in both in vitro and naturally grown L. cruciata. Alkaloids were present in different forms. 1-Butylpiperidine was found in an in-vitro grown $L$. cruciata while slightly modified form, Methyl 2-\{1-acetyl-5-ethyl-2-[3-(2-hydroxyethyl)$1 \mathrm{H}$-indol-2-yl]-4-piperidinyl $\}$ propanoate was found in naturally grown $L$. cruciata. Fatty acid and their esters were also present in both cases. Fatty acids like Ethyl tetradecanoate and Isopropyl stearate were present in an in vitro grown $L$. cruciata while, Cyclopentaneundecanoic acid, Methyl 11-cyclopentylundecanoate, Methyl (13E)13-docosenoate, and Methyl (13E,16E)-13,16- octadecadienoate were present in its naturally grown counterparts. However, the presence of alkanes was found only in naturally grown $L$. cruciata.

\section{Discussion}

In vitro propagation of $L$. cruciata was initiated from gemmae which started germinating after 8-12 days of inoculation. Spores of moss Erythrodontium julaceum and liverwort Marchantia linearis also required a similar time period for germination [23, 24]. Awasthi et al. [25] found a diluted nutrient medium to be the most suitable medium for germination of the spores of endangered liverwort Cryptomitrium himalayensis. In present work, different culture media such as Gamborg B-5, Knop, MS, and diluted MS/2 were used for optimizing micropropagation of L. cruciata. Among the media used, germination of gemmae was successfully initiated in half-strength Murashige and Skoog medium. The profound effect of growth regulators BAP and NAA were noticed on the growth and multiplication of thalli. Krishnan and Murugan [24] and Senarath et al. [26] used $2 \mathrm{mg} / \mathrm{L}$ BAP and $0.5 \mathrm{mg} / \mathrm{L}$ IAA for thallus and rhizoids differentiation of Marchantia linearis. In the present work, thallus and rhizoids differentiation from callus was initiated by supplementing basal salt media with $2 \mathrm{mg} / \mathrm{L}$ BAP and 0.5 $\mathrm{mg} / \mathrm{L}$ IAA. Alteration of hormone concentration at a 


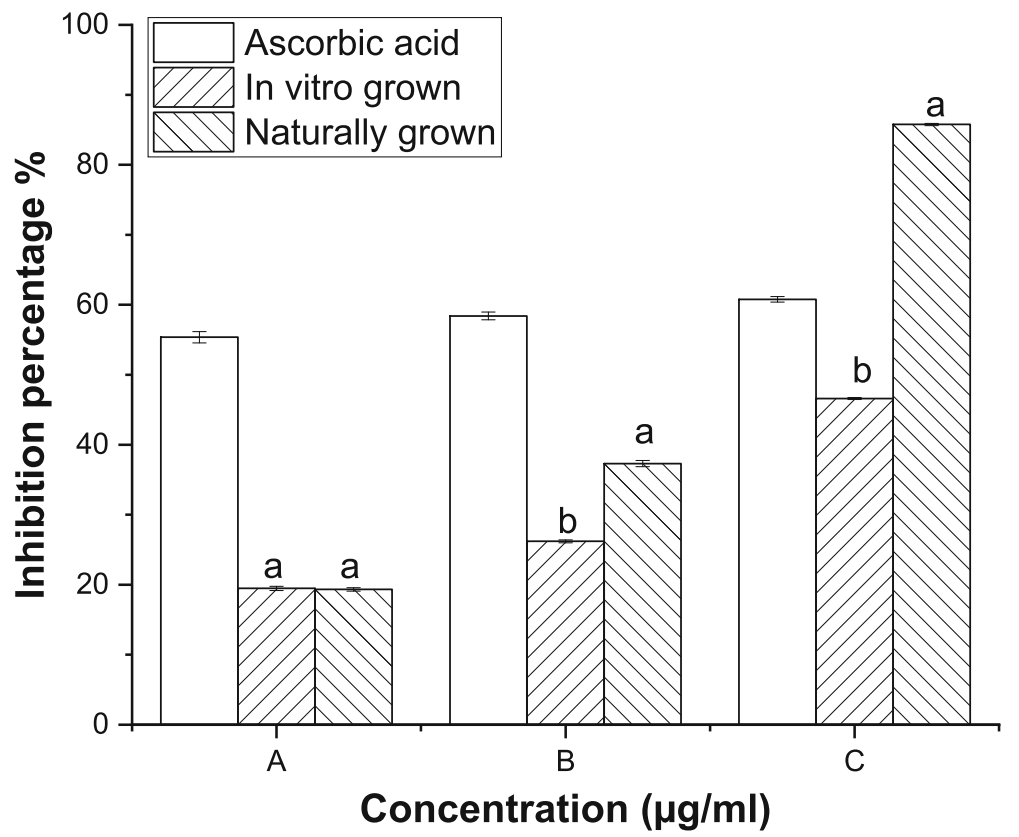

Fig. 4 Metal chelating activity of in vitro and naturally grown L. cruciata with their comparison with standard Ascorbic acid. Values with different letters $(a, b)$ are significantly $(p<0.05)$ different from each other by Turkey's multiple range test

Explanation of figure caption:

$\begin{array}{cc} & \text { Conc. of in vitro grown plants } \\ \mathrm{A}= & 450 \mu \mathrm{g} / \mathrm{ml} \\ \mathrm{B}= & 900 \mu \mathrm{g} / \mathrm{ml} \\ \mathrm{C}= & 4500 \mu \mathrm{g} / \mathrm{ml}\end{array}$

\author{
Conc. of naturally grown plants \\ $450 \mu \mathrm{g} / \mathrm{ml}$ \\ $900 \mu \mathrm{g} / \mathrm{ml}$ \\ $4500 \mu \mathrm{g} / \mathrm{ml}$
}

\section{Conc. of Standard \\ $20 \mu \mathrm{g} / \mathrm{ml}$ \\ $25 \mu \mathrm{g} / \mathrm{ml}$ \\ $30 \mu \mathrm{g} / \mathrm{ml}$}

later stage was found to be helpful. However, excess growth of rhizoids from the thallus was noticed at a later stage that hindered the growth of thallus. Increased BAP $(4 \mathrm{mg} / \mathrm{L})$ and decreased IAA concentration $(0.2 \mathrm{mg} / \mathrm{L})$ restricted the excessive growth of rhizoids and restored normal growth and multiplication of the thallus. Alternation of concentration of growth regulators was also found to be helpful by other researchers in achieving proper growth of bryophytes in an axenic condition. Krishnan and Murugan [24] achieved root induction by transferring the differentiating leafy thalli of Marchantia linearis in a rooting medium containing $2 \mathrm{mg} / \mathrm{L}$ IBA. This highlighted the importance of plant hormones in controlling the growth and proliferation of plants. Young thalli then grew continuously to develop dichotomously branched fully grown thalli after 12 weeks.

In vitro propagation provides the means for rapid multiplication of plants which helps to overcome various exertions related to the isolation of phytochemicals from wild varieties due to factors like seasonal dependence, lower material availability in nature, low rates of growth and over-exploitation of wild varieties. However, there is a possibility that there occurs alteration in the phytochemical composition of naturally grown plants due to change in biochemical pathways resulting from artificial growth system [26]. Thus, comparison of phytochemicals present in in vitro and naturally grown plants is essential if the axenically grown plants are to be used as an alternative to naturally grown plants [27]. The GC-MS analysis of methanolic extract showed the presence of nine compounds each in naturally grown and axenically grown $L$. cruciata. In the present study, the presence of many similar phytochemicals was found in naturally and axenically grown $\mathrm{L}$. cruciata. Synthesis of similar kind of phytochemicals in naturally and in vitro grown plants was also reported by Nikolova et al. [28] and Senarath et al. [26]. Alkaloids, flavonoids, terpenes, fatty acid, aliphatic hydrocarbon, and acyclic alkanes were the phytocompounds 


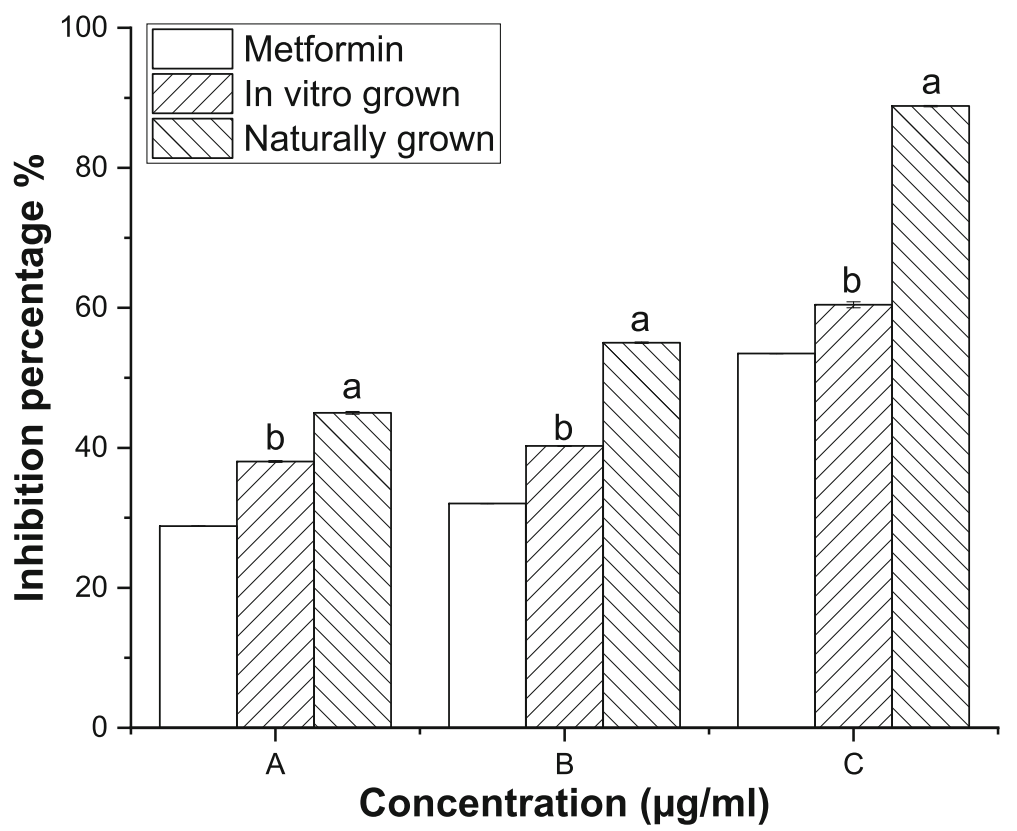

Fig. 5 a-glucosidase inhibitory activity of in vitro and naturally grown L. cruciata and their comparison with standard Metformin. Values with different letters $(a, b)$ are significantly $(p<0.05)$ different from each other by Turkey's multiple range test

Explanation of figure caption:

$\begin{array}{lc} & \text { Conc. of in vitro grown plants } \\ \mathbf{A}= & 350 \mu \mathrm{g} / \mathrm{ml} \\ \mathbf{B}= & 650 \mu \mathrm{g} / \mathrm{ml} \\ \mathbf{C}= & 3500 \mu \mathrm{g} / \mathrm{ml}\end{array}$

\author{
Conc. of naturally grown plants \\ $350 \mu \mathrm{g} / \mathrm{ml}$ \\ $650 \mu \mathrm{g} / \mathrm{ml}$ \\ $3500 \mu \mathrm{g} / \mathrm{ml}$
}
Conc. of Standard
$50 \mu \mathrm{g} / \mathrm{ml}$
$200 \mu \mathrm{g} / \mathrm{ml}$
$1000 \mu \mathrm{g} / \mathrm{ml}$

that have been detected in methanolic extract of axenically and naturally grown L. cruciata (Fig. 11 and Table 2). Compounds like flavone, phytol, and piperidine were common in both the plant extracts (Table 3), while, many other compounds differed slightly in structure, but belonged to same metabolite class and had similar retention time. Ethyl tetradecanoate present in an in-vitro grown and Cyclopentaneundecanoic acid present in naturally grown $L$. cruciata were fatty acids detected at similar retention time (18.03 and 18.08 respectively).

Alkaloids were detected in both the extracts. In an in vitro grown plant alkaloid was present in the form of 1-Butylpiperidine, while slightly modified ester form, Methyl 2-\{1-acetyl-5-ethyl-2-[3-(2-hydroxyethyl)-1H-indol-2-yl]-4-piperidinyl $\}$ propanoate was detected in naturally grown $L$. cruciata. Studies suggest that alkaloids present in plants have antimicrobial [29], cytotoxic [30], antimalarial activities [31], etc. Thus it can be assumed that the pharmacological activities showed by axenically and naturally grown L. cruciata might due to the presence of these bioactive phytochemicals. Another class of compound present was terpenes. Phytol was present in both extracts while [12]- thujopsene was present only in naturally grown plants. Terpenes are reported to be responsible for many important health beneficial activities like antimicrobial [32], antiinflammatory [33], anticancer [34], cardiovascular and diuretic activity [35]. Flavonoids like flavone were present in both naturally and in vitro grown $L$. cruciata while 3-Hydroxyflavone was present in naturally grown $L$. cruciata only. Flavonoids are important class of phytochemicals having many important activities like antioxidant [36], hepatoprotective [37], antibacterial [38], antiinflammatory [39] anticancer [40] and antiviral activity $[31,41]$. Thus it can be assumed that the pharmacological activities showed by axenically and naturally grown $L$. cruciata might due to the presence of bioactive phytochemicals like flavonoids, terpenes, and alkaloids, etc.

Fatty acid esters were also found; 2,4-tricosanedione was detected in an in vitro grown $L$. cruciata 


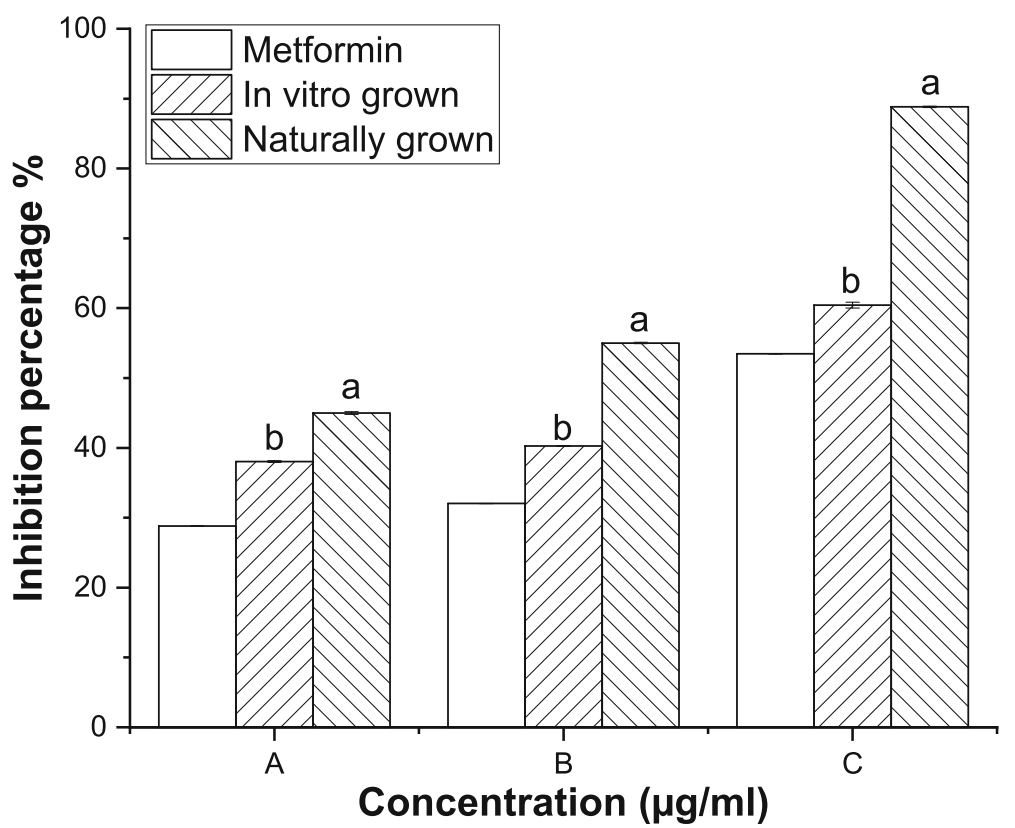

Fig. 6 a-amylase inhibitory activity of in vitro and naturally grown L. cruciata and their comparison with standard Metformin. Values with different letters $(a, b)$ are significantly $(p<0.05)$ different from each other by Turkey's multiple range test

Explanation of figure caption:

$\begin{array}{lc} & \text { Conc. of in vitro grown plants } \\ \mathbf{A}= & 300 \mu \mathrm{g} / \mathrm{ml} \\ \mathbf{B}= & 600 \mu \mathrm{g} / \mathrm{ml} \\ \mathbf{C}= & 3000 \mu \mathrm{g} / \mathrm{ml}\end{array}$

\author{
Conc. of naturally grown plants \\ $300 \mu \mathrm{g} / \mathrm{ml}$ \\ $600 \mu \mathrm{g} / \mathrm{ml}$ \\ $3000 \mu \mathrm{g} / \mathrm{ml}$
}

\section{Conc. of Standard \\ $50 \mu \mathrm{g} / \mathrm{ml}$ \\ $200 \mu \mathrm{g} / \mathrm{ml}$ \\ $1000 \mu \mathrm{g} / \mathrm{ml}$}

and Methyl (13E, 16E)-13,16-octadecadienoate; Methyl 11- cyclopentylundecanoate and Methyl (13E)-13-docosenoate was obtained in naturally grown L. cruciata.

GC-MS analysis has shown the presence of alkanes only in an in-vitro grown L. cruciata. In vitro grown Fossombronia pusilla has also produced the same terpenoid group as is produced by its natural counterparts [42]. Different fatty acid, fatty acid ester, fatty acid alcohol, and alkanes were synthesized in the in vitro grown $L$. cruciata like their natural counterparts. This suggests a possible application of in vitro cultured plants for clinical validation, bioprospection studies and commercial exploitation of novel compounds through bio farming without over-harvesting plants from their natural habitats. The presence of similar phytochemicals and biological activities in the in vitro and naturally grown plants were also reported by Vujcic et al. [43] and Senarath et al. [26].

Liverworts are moisture-loving plants with a restricted pattern of distribution growing mostly during the rainy season under natural condition [44, 45]. These drawbacks are responsible for their least use in research purposes. Also, their low availability in nature is the biggest challenge for the identification and isolation of biologically active phytochemicals insufficient amount from these plants [46]. Our finding supports the potential of in-vitro grown plants to overcome the challenges of seasonal dependence and low availability of liverworts for structural elucidation of compounds and biological assay. Potential of in-vitro grown plants to be used in place of naturally grown plants has also been reported by other researchers, like, two times increase in sesquiterpene was recorded by Otha et al. [47] in cell culture of liverwort Calypogeia granulata. Better production of effective phytochemical in artificial condition rather than natural habitat was also noticed by Sabovljevic et al. [48]. Different health beneficiary properties shown by herbal medicines are due to bioactive phytochemicals present in the plant [49, 50]. Presence of many phytochemicals in axenically 


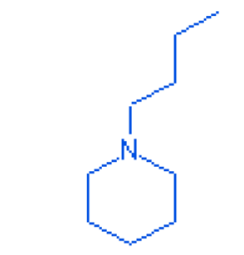<smiles>O=C1CCC=C1CC1=C(O)C(=O)CCC1</smiles><smiles>CC(=CCO)CCCC(C)CCCC(C)CCCC(C)C</smiles>

3-Hydroxy-2-[(5-oxo-1-cyclopenten1-yl)methyl]-2-cyclohexen-1-one

Phytol<smiles>O=c1cc(-c2ccccc2)oc2ccccc12</smiles>

Flavone<smiles>O=c1c(O)c(-c2ccccc2)oc2ccccc12</smiles>

3-Hydroxyflavone<smiles>CCCCCCCCCCCCCC(=O)OCC</smiles>

Ethyl tertradecanoate<smiles>CCC/C=C\CCCCCCCCCCOC(C)=O</smiles>

Z-13-octadecenyl acetate<smiles>CCCCCCCCCCCCCCCCCC(=O)OC(C)C</smiles>

Isopropyl stearate<smiles>CCCCCCCCCCCCCCCCCCCC(=O)CC(C)=O</smiles>

2, 4-Tricosanedione

Fig. 7 Structures of phytochemicals detected in the methanolic extract of an in vitro grown L. cruciata

and naturally grown plants was recorded through GC-MS analysis. In this work, antioxidative and anti-diabetic assays were performed to check whether the activity of phytochemicals of plant changes if grown in an artificial habitat. $\mathrm{DPPH}^{\cdot}$ is the stable organic nitrogen free lipophilic radical commonly used to investigate the free radical scavenging properties. $\mathrm{DPPH}^{\circ}$ scavenging activity was observed to be superior in axenically cultured plants (Fig. 4). Increased $\mathrm{DPPH}^{\circ}$ activity of in-vitro grown plants was also reported by Mohan et al. [51] in his work on Bacopa monnieri. Little improvement in free radical scavenging activity by in-vitro shoot extract was also reported by Manivannan et al. [27]. In a living system, free ferrous ions are the powerful pro-oxidants which cause oxidative damage and lipid peroxidation by Fenton reaction [50]. It is important to scavenge such radicals from the body of a living organism. On testing the in-vitro and naturally grown L. cruciata for the metal chelating property we have found that plant grown on both habitats have developed ability to scavenge ferrous ion. In this assay $\mathrm{Fe}^{2+}$ and ferrozine form complexes to produce hydroxyl radical, the chelating effect observed might be due to the interference of plant phytochemicals in the complex formation. Free radical 
<smiles>CC1=CC2(C)C(=CCCC2(C)C)CC1</smiles>

[12]-Thujopsene<smiles>O=c1cc(-c2ccccc2)oc2ccccc12</smiles>

Flavone<smiles>C/C=C/C/C=C/CCCCCCCCCCCC(=O)OC</smiles><smiles>CC(=CCO)CCCC(C)CCCC(C)CCCC(C)C</smiles>

Phytol<smiles>CCCCCCCCC=CCCCCCCCCCCCCC(=O)OC</smiles>

Methyl (13E)-13-docosenoate

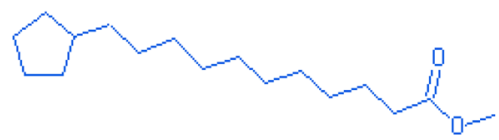<smiles>CC(=O)N1c2ccccc2C23CCN4CCCC(O)(CCC12)C43</smiles>

Deoxy aspidodispermine<smiles>CCC1CN(C(C)=O)C(c2[nH]c3ccccc3c2CCO)CC1C(C)C(=O)OC</smiles>

Methyl 2-\{1-acetyl-5-ethyl-2-[3-(2hydroxyethyl)-1H-indol-2-yl]-4-piperidinyl $\}$ propanoate

Methyl 11-cyclopentylundecanoate

Fig. 8 Structures of phytochemicals detected in the methanolic extract of naturally grown L. cruciata

scavenging property might be attributed to the presence of phenolic compounds like flavone, $4 \mathrm{H}-1$ Benzopyran-4-one, 3-hydroxy-2-phenyl present in the extracts. Phenolic compound acting as radical scavengers has also been reported by workers like Wong et al. [52] and Tusevski et al. [53]. Apart from the phenolic group, other bioactive metabolites like alkaloids, terpenoids identified might have contributed to biological activities. Reduction in insulin sensitivity and postprandial hyperglycemia are the characteristics of type 2 diabetes [54]. Lowering postprandial hyperglycemia can be an important measure to control diabetes. Postprandial hyperglycemia can be controlled by inhibiting the activity of enzymes $\alpha$ amylase and $\alpha$-glucosidase (carbohydrate hydrolyzing enzymes) [55]. In-vitro and naturally grown plants inhibited the activity of $\alpha$-amylase and $\alpha$-glucosidase enzymes to an impressive level (Fig. 6). Slightly better $\alpha$-glucosidase inhibitory activity was recorded in naturally grown $L$. cruciata in comparison to its in vitro grown counterparts. While, $\alpha$ - amylase activity was better in case of naturally grown plants. 


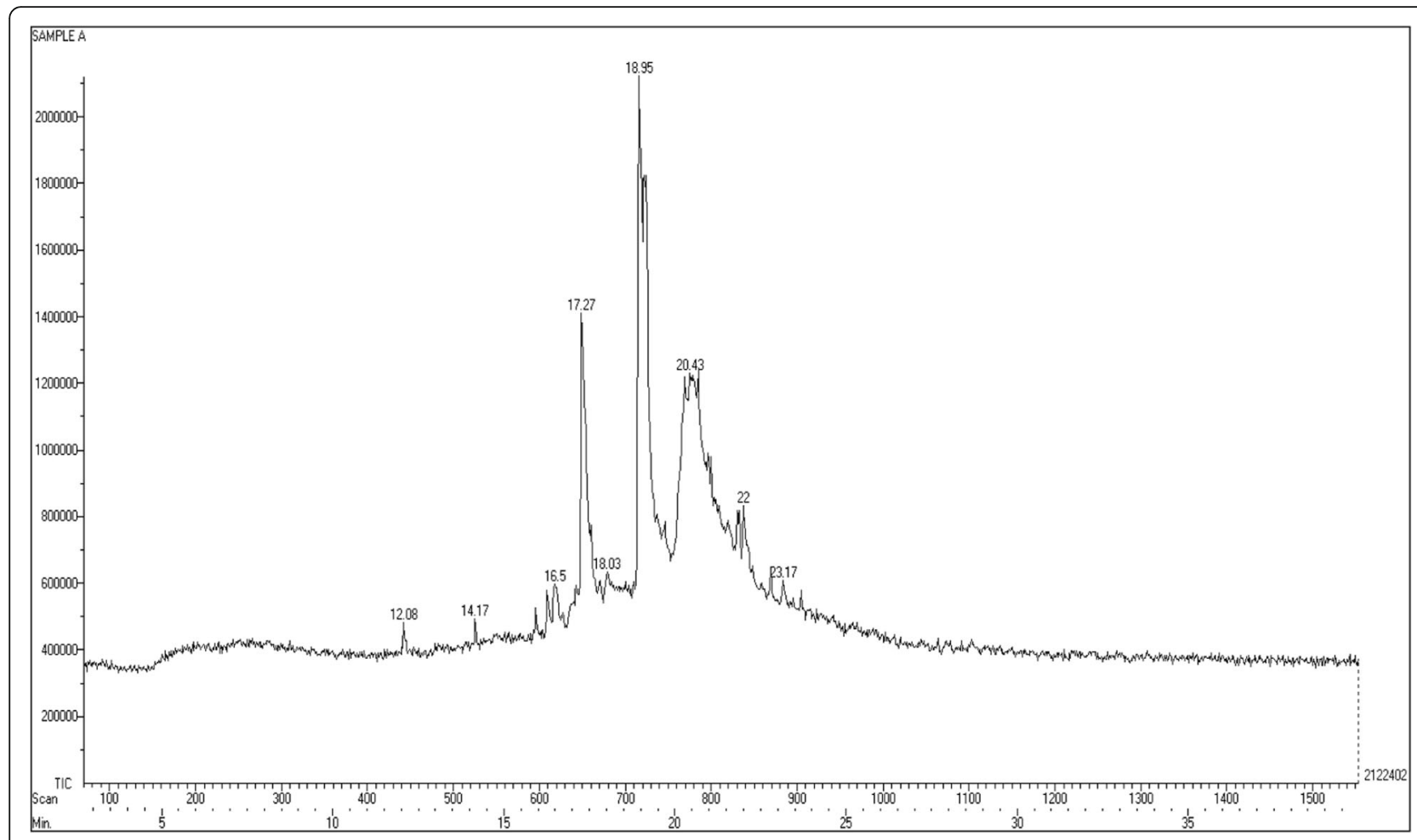

Fig. 9 Gas chromatogram with mass-spectrometric detection of the methanolic extract of an in vitro grown L. cruciata

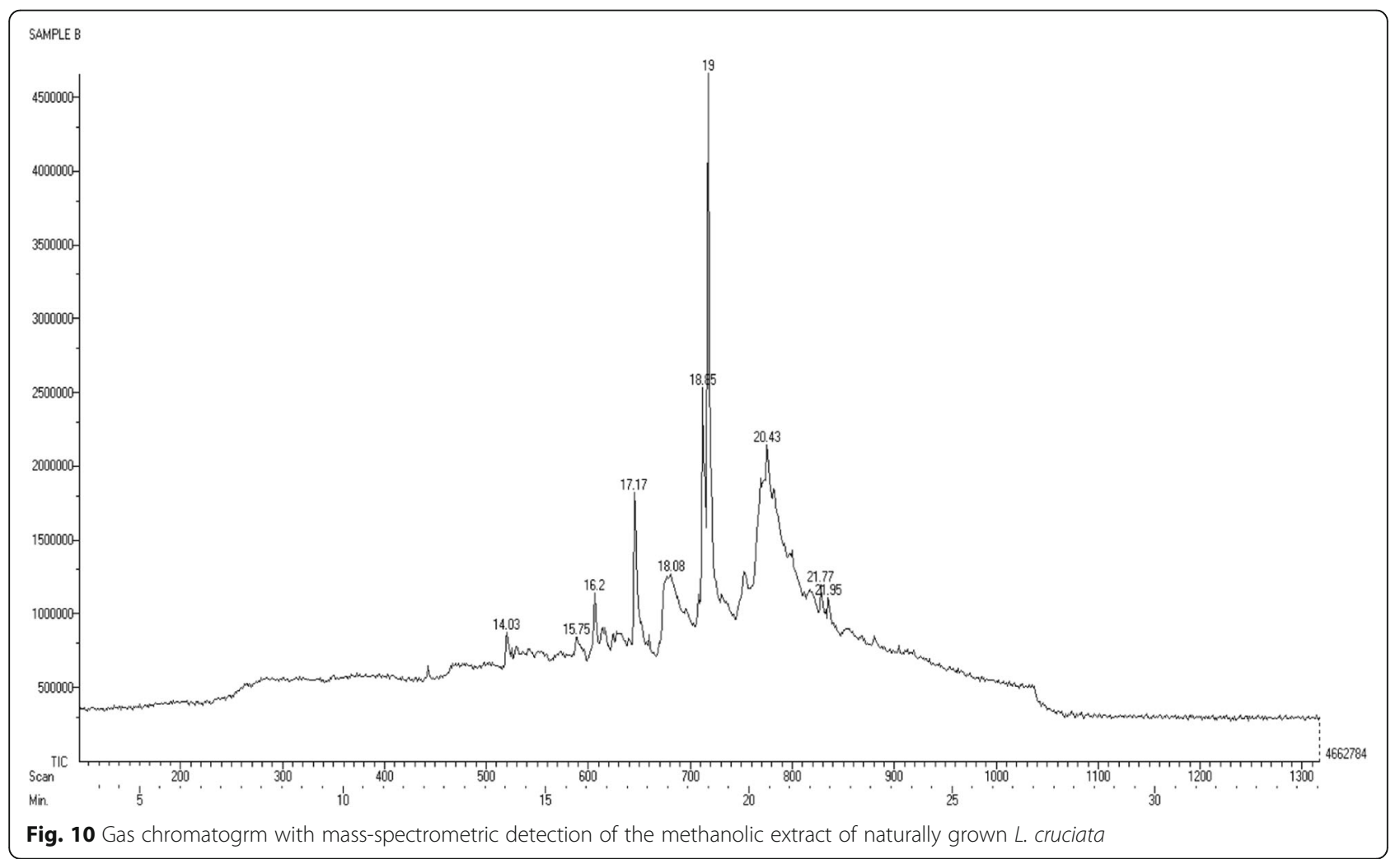


Table 2 Phytochemicals present in the methanolic extract of an in vitro grown L. cruciata and their biological activities

\begin{tabular}{|c|c|c|c|c|}
\hline Name & RT & $\mathrm{TIC}$ & Compound nature & Biological activities \\
\hline 1-Butylpiperidine & 12.08 & 481975 & alkaloid & Anti-microbial [29]; cytotoxic [30]; Antimalarial [31] \\
\hline $\begin{array}{l}\text { 3-Hydroxy-2-[(5-oxo-1-cyclopenten-1-yl) } \\
\text { methyl]-2-cyclohexen-1-one }\end{array}$ & 14.17 & & & No activities reported \\
\hline Flavone & 16.5 & 596325 & Flavonoid & $\begin{array}{l}\text { Antioxidant [36], Hepatoprotective [37], Antibacterial [38], } \\
\text { Anti-Inflammatory [39], Anticancer [40], Antiviral Activity [41] }\end{array}$ \\
\hline 3-Hydroxyflavone & 17.27 & 1412798 & Flavonols & $\begin{array}{l}\text { Antioxidant [36], Hepatoprotective [37], Antibacterial [38], } \\
\text { Anti-Inflammatory [39], Anticancer [40], Antiviral Activity [41] }\end{array}$ \\
\hline Ethyl tertradecanoate & 18.03 & 632812 & Fatty acid & No activities reported \\
\hline Phytol & 18.95 & 2122402 & Diterpene alcohol & $\begin{array}{l}\text { Antimicrobial [32], Anti-inflammatory [33], Anti cancer [34], } \\
\text { Cardiovascular and diuretic activity [35] }\end{array}$ \\
\hline Z-13-octadecenyl acetate & 20.43 & 1229732 & Aliphatic hydrocarbon & No activities reported \\
\hline Isopropyl stearate & 22 & 833849 & Fatty acid ester & No activities reported \\
\hline 2,4-Tricosanedione & 23.17 & 607218 & acyclic alkanes & No activities reported \\
\hline
\end{tabular}

\section{Conclusion}

The number of researches published related to phytochemical constituents and pharmacological properties of bryophytes are considerably low. The main reason that restricts the investigation on this group is the problem of sample availability in sufficient amount to carry on analysis of bioactivity with purified compounds obtained from bryophytes. In this work, Lunularia cruciata was grown under in-vitro conditions as an attempt to solve the problem of geographic and seasonal restriction of sample availability. Further the phytochemical composition and pharmacological properties of naturally grown and in vitro grown $L$. cruciata was compared to record changes in pharmacological properties and phytochemical composition. Result of the study showed no significant changes in the pharmacological properties of axenically cultured and naturally grown liverworts. Phytochemical constituents of two differently grown $L$. cruciata also did not vary much. Thus the results of this study validated the use of in vitro cultured plants as a substitute for naturally grown plants to overcome the shortcomings restricting the use of liverworts for therapeutic applications.

\section{Acknowledgments}

We are thankful to Sophisticated Analytical Instrument Facility (SAIF), IT Madras, India for providing facilities for GC-MS analysis. We are also grateful to the Director, Botanical Survey of India, Kolkata for facilitating the identification of the liverwort sample.

Table 3 Phytochemicals present in the methanolic extract of naturally grown L. cruciata and their biological activities

\begin{tabular}{|c|c|c|c|c|}
\hline Name & RT & $\mathrm{TIC}$ & $\begin{array}{l}\text { Compound } \\
\text { nature }\end{array}$ & Biological activities \\
\hline [12]-Thujopsene & 14.03 & 873686 & sesquiterpene & $\begin{array}{l}\text { Antimicrobial [32], Anti-inflammatory [33], Anti cancer [34], } \\
\text { Cardiovascular and diureticactivity [35] }\end{array}$ \\
\hline Flavone & 15.75 & 1138027 & Flavonoid & $\begin{array}{l}\text { Antioxidant [36], Hepatoprotective [37], Antibacterial [38], } \\
\text { Anti-Inflammatory [39], Anticancer [40], Antiviral Activity [41] }\end{array}$ \\
\hline Methyl 11-cyclopentylundecanoate & 17.17 & 1822103 & Fatty acid ester & No activities found \\
\hline Cyclopentaneundecanoic acid & 18.08 & 1274201 & Fatty acid & No activities found \\
\hline Methyl (13E, 16E)- 13,16 octadecadienoate & 18.85 & 2536991 & Fatty acid ester & No activities found \\
\hline Phytol & 19.03 & 2799556 & Diterpene alcohol & $\begin{array}{l}\text { Antimicrobial [32], Anti-inflammatory [33], Anti cancer [34], } \\
\text { Cardiovascular and diuretic activity [35] }\end{array}$ \\
\hline Deoxy aspidodispermine & 20.43 & 2148295 & alkaloid & No activities found \\
\hline Methyl (13E)-13-docosenoate & 21.77 & 1202092 & Fatty acid ester & No activities found \\
\hline $\begin{array}{l}\text { Methyl 2-\{1-acetyl-5-ethyl-2-[3-(2-hydroxyethyl)-1H- } \\
\text { indol-2-yl]-4-piperidinyl\} propanoate }\end{array}$ & 21.95 & 1105543 & Alkaloid & Anti-microbial [29]; cytotoxic [30]; Antimalarial [31] \\
\hline
\end{tabular}


Table 4 Comparison of phytochemicals present in the in vitro and naturally grown L. cruciata

\begin{tabular}{|c|c|c|c|c|c|c|c|}
\hline \multirow{2}{*}{$\begin{array}{l}\text { Sl. } \\
\text { No. }\end{array}$} & \multirow{2}{*}{ Compound class } & \multirow[b]{2}{*}{ In vitro } & \multicolumn{3}{|c|}{ Plant growth condition } & \multirow{2}{*}{$\begin{array}{l}\text { Retention } \\
\text { time }\end{array}$} & \multirow{2}{*}{$\begin{array}{l}\text { Relative } \\
\text { abundance }\end{array}$} \\
\hline & & & $\begin{array}{l}\text { Relative } \\
\text { abundance }\end{array}$ & $\begin{array}{l}\text { Retention } \\
\text { time }\end{array}$ & Naturally grown & & \\
\hline \multirow[t]{2}{*}{1} & Alkaloid & 1-Butylpiperidine & $23 \%$ & 12.08 & - & & \\
\hline & & - & & & $\begin{array}{l}\text { Methyl 2-\{1-acetyl-5-ethyl-2-[3-(2-hydroxyethyl)- } \\
\text { 1H-indol-2-yl]-4-piperidinyl\} propanoate }\end{array}$ & 21.95 & $40 \%$ \\
\hline \multirow[t]{2}{*}{2} & Terpenes & Phytol & $100 \%$ & 18.95 & Phytol & 19.03 & $100 \%$ \\
\hline & & - & & & [12]-Thujopsene & 14.03 & $31 \%$ \\
\hline \multirow[t]{2}{*}{3} & Flavonoid & Flavone & $28 \%$ & 16.5 & Flavone & 16.5 & $71 \%$ \\
\hline & & 3-Hydroxyflavone & $67 \%$ & 16.80 & - & & \\
\hline \multirow[t]{2}{*}{4} & Fatty acid & Ethyl tetradecanoate & $30 \%$ & 18.03 & - & & \\
\hline & & & & & Cyclopentaneundecanoic acid & 18.08 & $46 \%$ \\
\hline \multirow[t]{4}{*}{5} & Fatty acid ester & Isopropyl stearate & $39 \%$ & 22 & & & \\
\hline & & - & & & Methyl 11-cyclopentylundecanoate & 17.17 & $65 \%$ \\
\hline & & - & & & Methyl (13E, 16E)- 13,16 octadecadienoate & 18.85 & $91 \%$ \\
\hline & & - & & & Methyl (13E)-13-docosenoate & 21.77 & $43 \%$ \\
\hline 6 & $\begin{array}{l}\text { Aliphatic } \\
\text { hydrocarbon }\end{array}$ & $\begin{array}{l}\text { Z-13-octadecen-1yl } \\
\text { acetate }\end{array}$ & $58 \%$ & 20.43 & - & & \\
\hline 7 & Alkanes & Tricosane 2,4-dione & $29 \%$ & 23.17 & - & & \\
\hline
\end{tabular}

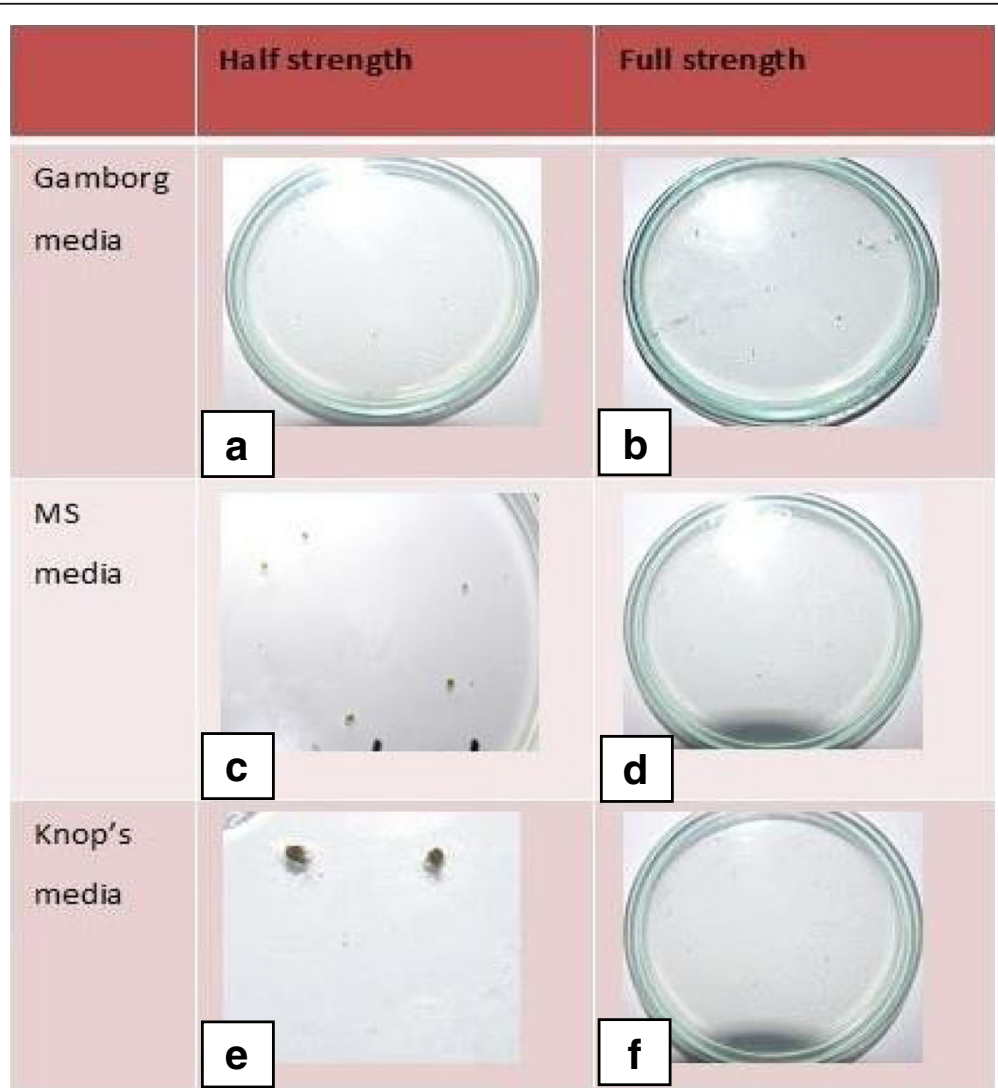

Fig. 11 Effect of different growth media on germination of gemmae. a: 0\% germination of gemmae; $\mathbf{b}$ : 0\% germination of gemmae; c: $90 \%$ germination of gemmae; $\mathbf{d}$ : $0 \%$ germination of gemmae; $\mathbf{e}=20 \%$ germination of gemmae; $\mathbf{f}: 0 \%$ germination of gemmae 


\section{Authors' contributions}

SM performed the experiment, analysis of data and wrote the first draft of the manuscript. PM designed the experiment and revised manuscript. DKS thoroughly revised and reformatted the manuscript and helped in the identification of liverwort sample studied in this work. DS helped in the identification and character study of liverwort sample studied. All authors read and approved the final manuscript.

\section{Funding}

Not applicable.

\section{Availability of data and materials}

All data generated or analyzed during this study are included in the manuscript and the raw data of the analysis will be made available on request.

\section{Ethics approval and consent to participate}

Collection of specimens used in this work was done according to regional and national guidelines. No permission was requested as the plant specimen used in this study is not under any protective figure.

\section{Consent for publication}

Not applicable.

\section{Competing interests}

The authors declare that they have no competing interests.

\section{Author details}

${ }^{1}$ Plant Physiology and Pharmacognosy Research Laboratory, Department of Botany, North Bengal University, P.O: NBU, Raja Rammohunpur, District, Darjeeling, West Bengal, India. ${ }^{2}$ Botanical Survey of India, CGO Complex, 3rd MSO Building, Salt Lake Sector I, Kolkata, West Bengal 700 064, India.

\section{Received: 12 October 2018 Accepted: 29 May 2019}

\section{Published online: 23 July 2019}

\section{References}

1. Dulger B, Yayintas OT, Gonuz A. Antimicrobial activity of some mosses from Turkey. Fitoterapia. 2005;76:730-2.

2. Ithan S, Savaroglu F, Colak F, Filik-Iseen C, Erderngil FZ. Antimicrobial activities of Palustriella commutate (Hedw.) ochyra extracts (Bryophyta). Turk J Biol. 2006;30:149-52.

3. Ojo OO, Ajayi AO, Anibijuwon II. Antibacterial potency of methanol extracts of lower plants. J Zhejiang Univ Sci B. 2007;8(3):189-91.

4. Sabovljevic A, Sabovljevic M. Bryophytes, a source of bioactive and compounds. In: Govil JN, Singh VK, editors. Phytopharmacology and therapeutic values IV, the series "recent Progress in medicinal plants". USA: Studium Press LLC; 2008. p. 9-25.

5. Niu C, Ou JB, Lou HX. Antifungal bisbibenzylsfrom the Chinese liverwort Marchantia polymorpha. Chem Biodivers. 2006;3:34-40.

6. Shen J, Li G, Liu Q, He Q, Gu J, Shi Y, Lou H. Marchantin C: a potential antiinvasion agent in glioma cells. Cancer Biol Ther. 2010;9:33-9.

7. Cheng $X$, Xiao $Y$, Wang $X$, Wang $\mathrm{O}, \mathrm{Li} H$, Yan H, Liu Q. Anti-tumor and proapoptic activity of ethanolic extract and its various fractions from Politrichum commune L. ex Hedw in L1210 cells. J Ethnopharmacol. 2012;143:49-56.

8. Wang XN, Yu WT, Lou HX. Antifungal constituents from the Chinese moss Homalia trichomanoides. Chem Biodivers. 2005;2:139-45.

9. Singh M, Govindarajan R, Nath V, Rawat AKS, Mehrotra S. Antimicrobial, wound healing and antioxidant activity of Plagiochasma appendiculatum Lehm et Lind. J Ethnopharmacol. 2006:107:67-72.

10. Harinantenaina L, Asakawa Y. Malagasy liverworts, source of new and biologically active compounds. Nat Prod Commun. 2004;2:701-9.

11. Wei HC, Ma SJ, Wu CL. Sesquiterpenoids and cyclic bisbibenzyls from the liverwortsReboulia hemisphaerica. Phytochemistry. 1995;39:91-7.

12. Asakawa Y. Chemical constituents of the bryophytes. In: Herz W, Kirby WB, Moore RE, Steglich W, Tamm CH, editors. Progress in the chemistry of organic natural products, vol. 65. Vienna: Springer; 1995. p. 1-618.

13. Servettaz C. Reserches experimentales sur le development et la nutrition des mousses en milieux sterilise. Ann Sci Nat. 1913:17:111-223.

14. Duckett JG, Burch J, Fletcher PW, Matcham HW, Read DJ, Russell AJ, Pressel S. In vitro cultivation of bryophytes: a review of practicalities, problems, progress, and promise. J Bryol. 2004;26:3-20.
15. Batra A, Binding $H$, Rasmussen $S$, Rudolph $H$, Waetzig $G H$. Efficient regeneration of Sphagnum fallax from isolated protoplasts. In Vitro Cell Dev Biol Plant. 2003;39(2):147-50.

16. Bijelovic A, Sabovljevic M, Grubisic D, Konjevic R. Phytohormone influence on the morphogenesis of two mosses (Bryum argenteum Hedw. And Atrichum undulatum (Hedw.) P. Beuav.). Isr J Plant Sci. 2004;52(1):31-6.

17. Sabovljevic A, Sabovljevic M, Grubisic D, Konjevic R. The effect of sugars on development of two moss species (Bryum argenteum and Atrichum undulatum) during in vitro culture. Belg J Bot. 2005;138(1):79-84.

18. Rowntree JK, Ramsay MM. How bryophytes came out of the cold: successful cryopreservation of threatened species. Biodivers Conserv. 2009;18:1413-20.

19. Sidduraju P, Mohan P, Becker K. Studies on the antioxidant activity of Indian Laburnum Cassia fistula L: a preliminary assessment of crude extracts from stem bark, leaves, flowers, and fruit pulp. Food Chem. 2002;79(1):61-7.

20. Li XC, Wu XT, Huang L. Correlation between antioxidant activities and phenolic contents of Radix Angelicae sinensis (Danggui). Molecules. 2009; 14(12):5349-61.

21. Dinis TCP, Madeira VM, Almeida LM. Action of phenolic derivates (acetoaminophen, salicylate, and 5-aminosalycilate) as inhibitors of membrane lipid peroxidation and as peroxyl radical scavengers. Arch Biochem Biophys. 1994;315(1):161-9.

22. Kim Ym, Jeong $Y K$, Wang $M H$, Lee $W$, Rhee $H$. Inhibitory effect of pine extract on a-glucosidase activity and postprandial hyperglycemia. Nutrition. 2005;21(6):756-61.

23. Awasthi $V$, Nath $V$, Asthana AK. In vitro regeneration and micropropagation of some liverworts from vegetative explants. Natl Acad Sci Lett. 2012. https://doi.org/10.1007/s40009-011-0001-y.

24. Krishnan R, Murugan K. Axenic culture of bryophytes: A case study of liverwort Marchantia linearis Lehm. \& Lindenb. Indian J Biotechnol. 2014;13: 131-5.

25. Awasthi $\bigvee$, Asthana AK, Nath $\vee$. In- vitro study on the reproductive behavior of the endemic and threatened Indian liverwort: Cryptomitrium himalayense Kashyap(Aytoniaceae) Cryptogamie Bryol. 2013;34(3):313-23.

26. Senarath RMUS, Karunarathna BMAC, Senarath WTPSK, Jimmy GC. Invitro propagation of Kaempferia galanga (Zingiberaceae) and comparison of larvicidal activity and phytochemical identities of rhizomes of tissue cultured and naturally grown plants. J Appl Biotechnol Bioeng. 2017;2(4):1-6.

27. Manivannan A, Soundararajan P, Park YG, Jeong BR.: In vitro propagation, phytochemical analysis, and evaluation of free radical scavenging property of Scrophularia kakudensis franch tissue extracts. Biomed Res Int. 2015; Article ID 480564. https://doi.org/10.1155/2015/480564.

28. Nikolova M, Petrova M, Zayova E, Vitkova A, Evstatieva L. Comparative study of in vitro, ex vitro and in vivo grown plants of Arnica montana - polyphenols and free radical scavenging activity. Acta Bot Croat. 2013;72(1):13-22

29. Kumar P, Sharma B, Bakshi N. Biological activity of alkaloids from Solanum dulcamara L. Natl Prod Res. 2009;23(8):719-23.

30. Rinaldi MVN, Diaz IEC, Suffredini IB, Moreno PRH. Alkaloids and biological activity of beriba (Annona nypoglauca). Braz J Pharm. 2017; 27:77-83

31. Wirasathien L, Boonarkart C, Pengsuparp T, Suttisri R. Biological activities of alkaloids from Pseuduvaria setose. Pharm Biol. 2006;44(4):274-8.

32. Cardoso SAN, Cavalcante TT, Araujo AX, Dos Santos HS, Albuquerque MR, Bandeira PN, Da Cunha RM, Cavada BS, Teixeira EH. Antimicrobial and antibiofilm action of Casbane diterpene from Croton nepetaefolius against oral bacteria. Arch Oral Bio. 2012;57(5):550-5.

33. Khiev P, Oh SR, Chae HS, Kwon OK, Ahn KS, Chin YW, Lee HK. Antiinflammatory diterpene from Thyrsanthera suborbicularis. Chem Pharm Bull (Tokyo). 2011;59(3):382-4

34. Islam MT. Diterpenes and their derivatives as potential anticancer agents. Phytother Res. 2017;31(5):691-712.

35. Somova LI, Shode FO, Moodley K, Govender Y. Cardiovascular and diuretic activity of kaurene derivatives of Xylopia aethiopica and Alepidea amatymbica. J Ethnopharmacol. 2001;77:165-74.

36. Pietta PG. Flavonoids as antioxidants. J Nat Prod. 2000;63(7):1035-42.

37. Akachi $T$, Shiina $Y$, Ohishi $Y$, Kawaquchi $T$, Kawaqishi $H$, Morita T, Mori T, Mori M, Suqiyama K. Hepatoprotective effects of flavonoids from shekwasha (Citrus depressa) against D- galactosamine-induced liver injury in rats. J Nutr Sci Vitaminol (Tokyo). 2010;56(1):60-7. 
38. Cushnie TP, Lamb AJ. Antimicrobial activity of flavonoids. Int J Antimicrob Agents 2005;26(5):343-56.

39. Serafini M, Peluso I, Raquzzini A. Flavonoids as anti-inflammtory agents. Proc Nutr Soc. 2010;69(3):273-8.

40. Zhang Y. Seeram NP, Lee R, Feng L, Hebe D. Isolation and identification of strawberry phenolics with antioxidant and human cancer cell antiproliferative properties. J Agric Food Chem. 2008;56:670-5.

41. Lani R, Hassandarvish P, Shu MH, Phoon WH, Chu JJ, Higgs S, Vanlandingham D, Abu Bakar S, Zandi K. Antiviral activity of selected flavonoids against Chikungunya virus. Antivir Res. 2016;133:50-61.

42. Sauerwein M, Becker H. Growth terpenoid production and antibacterial activity of an in vitro culture of a liverwort Fossombronia pusilla. Planta Medica. 1990;56:364-7.

43. Vujcic V, Brkanac SR, Redovnikovic IR, Ivankoviv S, Stojkovic R, Zilic I. Phytochemical and bioactive potential of in vivo and in vitro grown plants of Centaurea ragusina L. - detection of DNA/RNA active compounds in plant extracts via thermal denaturation and circular dichroism. Phytochem Anal. 2017;28:584-92.

44. Singh DK. Indian hepaticae: status and strategies. Ann For Sci. 1999;7(2): 199-211.

45. Bhattacharya SD. Threats and conservation of liverworts in India: an overview. Biol Environ Sci. 2011;7:168-72.

46. Klavina L, Gunta S, Nikolajeva V, Marsinkevich I, Nakurte I, Dzabijeva D, Steinberga I. Chemical composition analysis, antimicrobial activity and cytotoxicity screening of moss extracts (Moss phytochemistry). Molecules. 2015;20:17221-43

47. Ohta Y, Katoh K, Takeda R. Growth and secondary metabolites in cultured cells of liverworts. In: Chopra RN, Bhatla SC (eds) Bryophyte development: physiology and biochemistry. Boston: CRC Press; 1990. p. 209-23.

48. Sabovljevic A, Sokovic M, Glamoclija J, Cirirc A, Vujicic M, Boris P, Sabovljevic M. Bio-activities of extracts from some axenically framed and naturally grown bryophytes. J Med Plans Res. 2011;5(4):565-71.

49. Sahoo S, Ghosh G, Das D, Nayak S. Phytochemical investigation and in vitro antioxidant activity of an endogenous medicinal plant Alpinia nigra B.L, Burtt. Asian Pac J Trop Biomed. 2013;3:871-6.

50. Saravanam S, Parimelazhagan T. In-vitro antioxidant, antimicrobial and antidiabetic properties of polyphenols of Passiflora ligularis Juss. fruit pulp. Food Sci Human Wellness. 2014;3:56-64.

51. Mohan N, Jassal PS, Kumar V, Singh RP. Comparative in-vitro and naturally study of antioxidants and phytochemical content in Bacopa monnieri. Recent Res Sci Technol. 2011;3:78-83.

52. Wong SP, Lai PL, Jen HWK. Antioxidant activities of aqueous extracts of selected plants. Food Chem. 2006;99:775-83.

53. Tusevski O, Stanoeva JP, Stefoya M, Simic SG. Phenolic profile of dark-grown and photoperiod exposed Hypericum perforatum L. hairy root cultures. Sci World J. 2013. Article ID 602752.

54. Mousinho NMHDC, Tonder JJV, Vanessa S. In vitro anti-diabetic activity of Sclerocarya birrea and Ziziphus mucronata. Nat Prod Commun. 2013;8: 1279-84.

55. Ali H, Houghton PJ, Soumyanath A. a-Amylase inhibitory activity of some Malaysian plants used to treat diabetes; with particular reference to Phyllanthus amarus. J Ethnopharmacol. 2006;107(3):449-55.

\section{Publisher's Note}

Springer Nature remains neutral with regard to jurisdictional claims in published maps and institutional affiliations.

Ready to submit your research? Choose BMC and benefit from:

- fast, convenient online submission

- thorough peer review by experienced researchers in your field

- rapid publication on acceptance

- support for research data, including large and complex data types

- gold Open Access which fosters wider collaboration and increased citations

- maximum visibility for your research: over $100 \mathrm{M}$ website views per year

At BMC, research is always in progress.

Learn more biomedcentral.com/submissions 